\title{
Comparative Study of MPPT Techniques for Photovoltaic Systems
}

\author{
Omorogiuwa Eseosa*, Itelema Kingsley
}

Electrical/Electronic Engineering, Faculty of Engineering, University of Port Harcourt, Rivers State, Nigeria

DOI: $\underline{10.36348 / \text { sjet.2020.v05i02.002 }}$ | Received: 14.01 .2020 | Accepted: 23.01 .2020 | Published: 14.02 .2020

*Corresponding author: Omorogiuwa Eseosa

\section{Abstract}

Currently, one of the most efficient and cleanest forms of renewable energy source for effective power generation is Photovoltaic (PV) source. It is because of its cheapness, almost free maintenance cost, friendliness to the environment etc. However tracking the sun energy with the solar panels for effective utilization of its energy still pose a major challenge to researchers. Hence tracking these energy is very important. The paper is on simulation of MPPT using P\&O and INC methods. Mathematical model of 100KW PV system was developed using Matlab M-file. Both models were designed and simulated using MATLAB/SIMULINK. It is shown that PV system output power increases with rise in solar irradiation and in lower cell temperature. Therefore, solar cell performs better in warm environment than cold environment. The $\mathrm{P} \& \mathrm{O}$ gives the best duty cycle as compared to constant time interval control in getting the PV system's highest power and the INC method extract a high maximum power than P\&O. Both popular MPPT methods were used in the simulation which was controlled by the signal builder and the results displayed. It was observed that INC MPPT has better performance than $\mathrm{P} \& \mathrm{O}$ algorithm. The voltage obtained from the panel system is increased by the DC-DC boost circuit with a load resistance connected to it. It is recommended that the MPPT The system should consist of fractional, three-point, temperature-based MPPT for more effective and improved comparison. Moreso the perturb and observed method should be improved on by varying of the irradiance to maintain an increase constant voltage.

Keywords: Renewable Energy, MPPT, P\&O, INC, PV.

Copyright @ 2020: This is an open-access article distributed under the terms of the Creative Commons Attribution license which permits unrestricted use, distribution, and reproduction in any medium for non-commercial use (NonCommercial, or CC-BY-NC) provided the original author and source are credited.

\section{INTRODUCTION}

The fact that electricity is a major essential necessity for humans at present cannot be overemphasized. Pollution due to fossil fuels is reduced drastically because of introduction of solar energy; thus increasing the value of electricity generation. Renewable energy is the best alternative among all resources to fulfill the plea of energy [1]. Renewable energy sources comprises of wind energy, solar energy, tidal energy, etc. These sources are famous due to these advantages e.g. reliability, availability, environmentally friendly, long life span, low cost of maintenance and free of pollution [2]. The sun energy is an important source of energy for electricity generation. The sun generates large amount of energy. In one hour, it can generate enough power for the world in one year. However, due to low efficiency of current solar panels, conversion of sunlight into electrical power is very poor. This efficiency further reduces if there is no load matching between the input side (PV array output) and the output side (load) according to Liu et al., in 2015 [3]. Operating the panels at its highest power point is very important so as to make large as possible the solar panel power to get a rise in output efficiency [4]. Consequently, an on-line monitoring of the highest power point is a necessary part of any PV system when it becomes different with the solar irradiance and cell temperature. Figure-1 shows a picture of a solar panel.

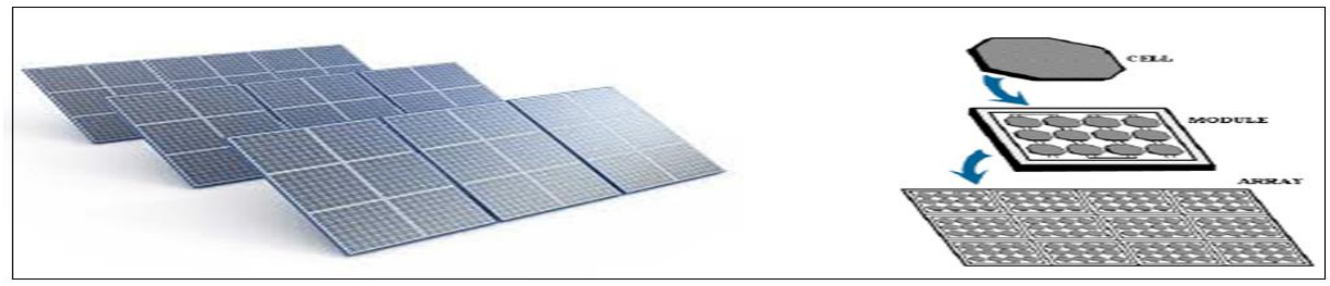

Fig-1: Solar Panel

Source: Google.com/solar 
At the moment, the most encouraging source of renewable power is Photovoltaic (PV) power generation. PV power generation is favored over other renewable power sources owing to its environmental and cheap benefits, since it is pure, unlimited and demand insignificant maintenance [5]. Transforming solar power to electricity is done plainly from the power the PV cells produce. In order to power the loads, PV arrays produce direct current (DC) which is converted to alternating current (AC). Hence, PV systems need power converters to connect PV arrays and the grid [6]. In essence, load impedance, solar irradiation and temperature determines the solar panel output. To such an extent, since the load impedance depends on the application, and to increase the performance of solar panel, dc-dc converter is used. The aim of this paper is to comparatively study MPPT techniques for photovoltaic systems. The objectives include:

- To investigate various MPPTs employed in PV systems.

- To comparatively study Incremental Conductance (INC) and Perturb \& Observe (P\&O) MPPTs used in PV systems.

- To determine which MPPT is suitable for obtaining maximum power.

\section{REVIEW OF RELATED WORKS}

Power system networks take the PV-generated energy by means of grid-connected inverters. There is sometimes, no matching of the operating distinctive features of the load and PV arrays, which is a notable difficulty in PV power systems. Specifically, with different environmental state, PV Module array displays non-linear style for V-I curve and maximum power point on V-P curve. PV module efficiency is in the range of $10-25 \%$. What this means is maximum power point tracking (MPPT) algorithms are joined with the entire system to maximize their ability and reduce modules cost. To rise up its efficiency under these changing conditions, these PV systems usually make use of MPPT techniques. In the nutshell, MPPTs are used to increase the system power output [7]. Lately, renewable energy technology has played significant part in energy application. One worthy type of renewable energy is energy from the sun that generates electrical power directly by using PV modules aided by MPPT algorithms to make as large as possible the solar output power. In a nutshell, by modifying the output power of the inverter, the goal of achieving MPPT in PV systems is to adjust the possible operating voltage of PV panels to the voltage at MPPT [7]. However, in literatures, there are ample amounts of MPPT methods as investigated by the following researchers [8, 9, 3]. Some common MPPTs are known Perturb and Observe (P\&O), Incremental Conductance (INC), Open circuit voltage $\left(\mathrm{V}_{\mathrm{OC}}\right)$ and Short Circuit Current (ISC), ripple correlation current and stochastic-based MPPT algorithms (Artificial Intelligence network, Fuzzy Logic Controller and differential evolution). Liu et al., in 2015 gave critical evaluation of MPPT techniques for use in incompletely shaded conditions [3]. Tracking techniques are grouped in three types: conventional MPPT techniques, global MPPT techniques, and power electronics-based approaches [10]. However, to aid users decide an appropriate MPPT technique for a specific application; this paper presents concise comparison between the different techniques. Cost, analog or digital implementation, uniform speed, hardware intricacy, and decisive effects are the reasons for comparison between MPPT methods. Incremental Conductance (INC), Perturb and Observe (P\&O), Constant Current (CI) and Constant Voltage (CV) are the most frequently employed methods [11]. Perturb and Observe $(\mathrm{P} \& \mathrm{O})$ and Incremental Conductance (INC) MPPTs are the major methods discussed in this paper. Under changing solar irradiation and temperature state, the performance of both techniques are examined and compared by means of analysis and digital simulations using Matlab/Simulink. Due to power fluctuations when there is solar irradiance and temperature change, the efficiency of PV module is low and there is need for the load to get the highest power available, hence an MPPT technique is employed in the system [12]. The likely mismatch between the operating load distinctive features and PV module array is significant difficulty in PV systems which results in major loss in efficiency and also, inability to get the highest power during environmental effects (e.g. Temperature change and solar irradiation) [13]. Fortunately, this problem can be solved using MPPT algorithm that keeps the PV array at highest power point [6].

\section{METHODOLOGY}

Using a single diode equivalent circuit makes it easy to model the PV characteristics. Matlab/Simulink tool is used to develop the mathematical model of PV cell. The basic equation that mathematically describes the I-V characteristic of an ideal PV cell is given as;

$$
\begin{aligned}
& I=I_{p v(c e l l)} I_{d} \ldots \ldots \ldots \ldots \ldots \ldots \ldots \ldots \ldots \ldots \ldots \\
& \text { Where } I_{d}=I_{\text {ocell }}\left[\exp \left[\left(\frac{q v}{a k T}\right)-1\right] \ldots \ldots \ldots \ldots 2\right.
\end{aligned}
$$

Substituting $\mathrm{I}_{\mathrm{d}}$ in equation 1 gives equation 2;

$$
I_{p v(c e l l)} I_{o(c e l l)}\left[\exp \left[\left(\frac{q v}{a k T}\right)-1\right] \ldots \ldots \ldots \ldots . . .3\right.
$$

Where;

$\mathrm{I}_{\mathrm{pv}(\mathrm{cell})}=$ incident light current that is directly proportional to the sun irradiation.

$\mathrm{I}_{\mathrm{d}}=$ Diode equation, $\mathrm{V}=$ output voltage, $\mathrm{I}_{\mathrm{o}(\mathrm{cell})}$

$=$ Reverse saturation/leakage current of diode, $\mathrm{q}=$ Electron charge constant $(1.60217646 \mathrm{x}$ $\left.10^{-19} \mathrm{C}\right), \mathrm{k}=$ Boltzmann constant $(1.3806503 \mathrm{x}$ $\left.10^{-23} \mathrm{~J} / \mathrm{K}\right), \mathrm{T}=$ Temperature of the $p-n$ junction in $(\mathrm{K}), \mathrm{a}=$ diode ideality constant.

Figure-2 shows equivalent circuit of an ideal PV cell. 


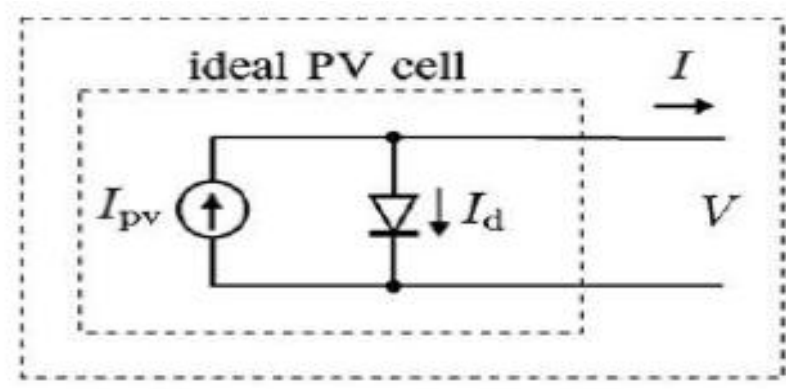

Fig-2: Circuit Equivalent of Ideal PV cell [6]

\section{PV Array Modeling}

PV array is a combination of 5 solar cells in series and 66 parallel modules connected together. The system current and voltage is outputted to the other unit. Other parameters are added in the distinctive feature of the PV array terminals which resulted to equation 4 ;

$$
\mathrm{I}=\mathrm{I}_{\mathrm{pv}}-\mathrm{I}_{\mathrm{o}}\left[\exp \left(\frac{\mathrm{V}+\mathrm{IRs}}{V t a}\right)-1\right]-\frac{\mathrm{V}+\mathrm{IRs}}{R p} \ldots \ldots \ldots 4
$$

Where $\mathrm{V}_{\mathrm{t}}=\frac{N s k T}{q}$ (thermal voltage) and Ns cells $=$ series connected cells. In parallel cell connection, the current increases and in series connection, the voltage output is large. $V$ and $I$ are the terminal voltage and current. With resistance in series, $\mathrm{R}_{\mathrm{s}}$ and resistance in parallel, $R_{p}$ connected as shown gives equivalent circuit of an ideal PV as described in Figure-3.

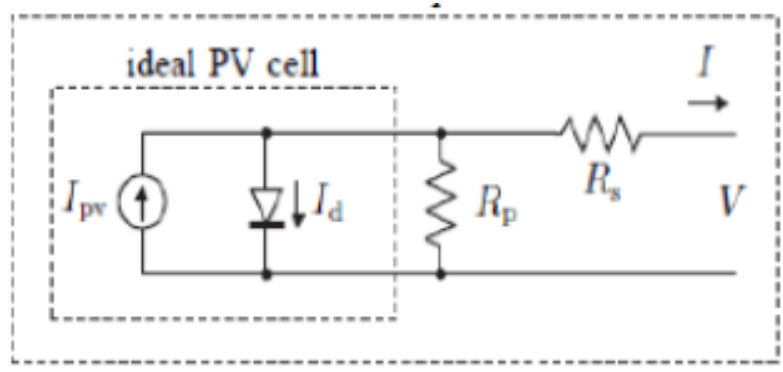

Fig-3: Equivalent Circuit of $P V$ cell with $R_{s}$ and $R_{p}[6]$

In order to obtain a good solar cell, $\mathrm{R}_{\mathrm{s}}$ should be made small and $R_{p}$ large. The current-voltage (I-V) is described in Figure-4(a) and has three relevant parameters (i.e. $\mathrm{I}_{\mathrm{sc}}, \mathrm{V}_{\mathrm{oc}}$ and MPP). Temperature and solar irradiance determines the I-V characteristics of the PV cell.
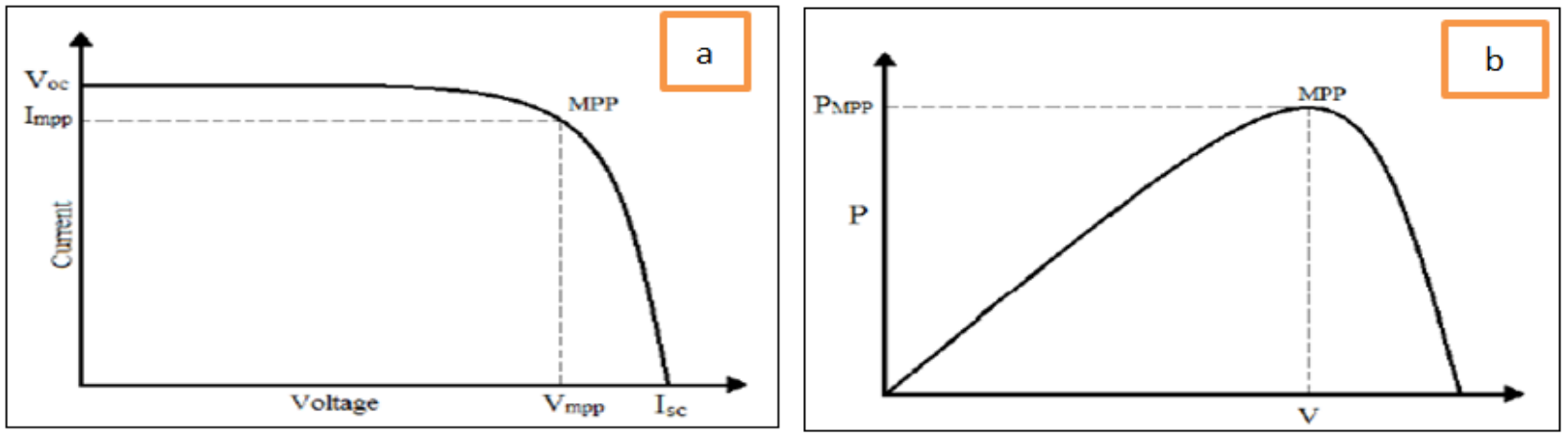

Fig-4: (a): I-V Characteristics (b) P-V Characteristics

Source: Christopher et al., 2013 [6]

Figure-4 illustrates P-V characteristics which also depend on $\left(\mathrm{I}_{\mathrm{sc}}, \mathrm{V}_{\mathrm{oc}}\right.$ and MPP).sw

\section{Design Analysis}

PV systems used for this study are combinations of PV modules (5 series and 66 parallel) connected together. PV modules are a combination of solar cells. The system supplies current and voltage by transformation of solar energy into electrical energy. PV array relies on the temperature and irradiation of the sun light that strikes the solar array. The higher the irradiance, the higher the voltage and current. Similarly, the lower the temperature, the lower the operating point current and voltage.

\section{MPPT System}

MPPT matches source impedance with load impedance and this is obtained by employing DC-DC converter. The converter is the interface between the PV module and load as described in Figure 3.4. The source impedance matches the load impedance by varying the time (duty) cycle in order to obtain the highest power possible [14]. If a step-down converter has an output voltage, $\mathrm{V}_{\mathrm{o}}$, input voltage, $\mathrm{V}_{\mathrm{i}}$ and time (duty) cycle, $\mathrm{D}$, the equation is given as shown in equation 5;

$$
\mathrm{V}_{\mathrm{o}}=\mathrm{D} \times \mathrm{V}_{\mathrm{i}} \ldots \ldots \ldots \ldots \ldots \ldots \ldots \ldots
$$

Where $R_{o}$ and $R_{i}$ are output and input impedance respectively. The impedance equation becomes equation $6 \& 7$ respectively.

$$
\begin{aligned}
& \mathrm{R}_{\mathrm{o}}=\mathrm{D}^{2} \times \mathrm{R}_{\mathrm{i}} \ldots \ldots \ldots \ldots \ldots \ldots \ldots \ldots \ldots \ldots \ldots \ldots \ldots \ldots \ldots \\
& \text { And } \mathrm{R}_{\mathrm{i}}=\frac{R o}{D 2} \ldots \ldots \ldots \ldots \ldots \ldots \ldots \ldots \ldots
\end{aligned}
$$

\section{MPPT System Parameters}

Solar panel model was used in the modeling and the data used are as shown in Table-1. Figure-5 shows the PV model in Matlab Simulink environment while. Fig-5 shows the model Block Parameters of PV Array in Matlab/Simulink environment. 
Table-1: Block Parameters of PV Array

\begin{tabular}{|l|l|}
\hline Solar Panel Model & SunPower SPR-305 \\
\hline Solar Panel Wattage & 305 Watt $(\mathrm{Wp})$ \\
\hline MPP Voltage & 54.7 Volts \\
\hline $\mathrm{I}_{\mathrm{sc}}$ & $5.96 \mathrm{Amps}$ \\
\hline $\mathrm{V}_{\mathrm{oc}}$ & $64.2 \mathrm{Volts}$ \\
\hline MPP Current & $5.58 \mathrm{Amps}$ \\
\hline No. of Panels in Parallel & 66 \\
\hline No. of Panels in Series & 5 \\
\hline Total Power of System at MPP & $305 \times 66 \times 5=100.65 \mathrm{KW}$ \\
\hline Temperature Coefficient $\left(\mathrm{V}_{\text {oc }}\right)$ & $-0.27269 \% /{ }^{\circ} \mathrm{C}$ \\
\hline Temperature Coefficient $\left(\mathrm{I}_{\mathrm{sc}}\right)$ & $0.061745 \% /{ }^{\circ} \mathrm{C}$ \\
\hline Boost Converter Output $\mathrm{V}_{\text {oltage }}$ & $500 \mathrm{Volts}$ \\
\hline Boost Converter Switching Frequency & $5 \mathrm{kHz}$ \\
\hline Boost Converter Inductance & $5 \mathrm{mH}$ \\
\hline
\end{tabular}

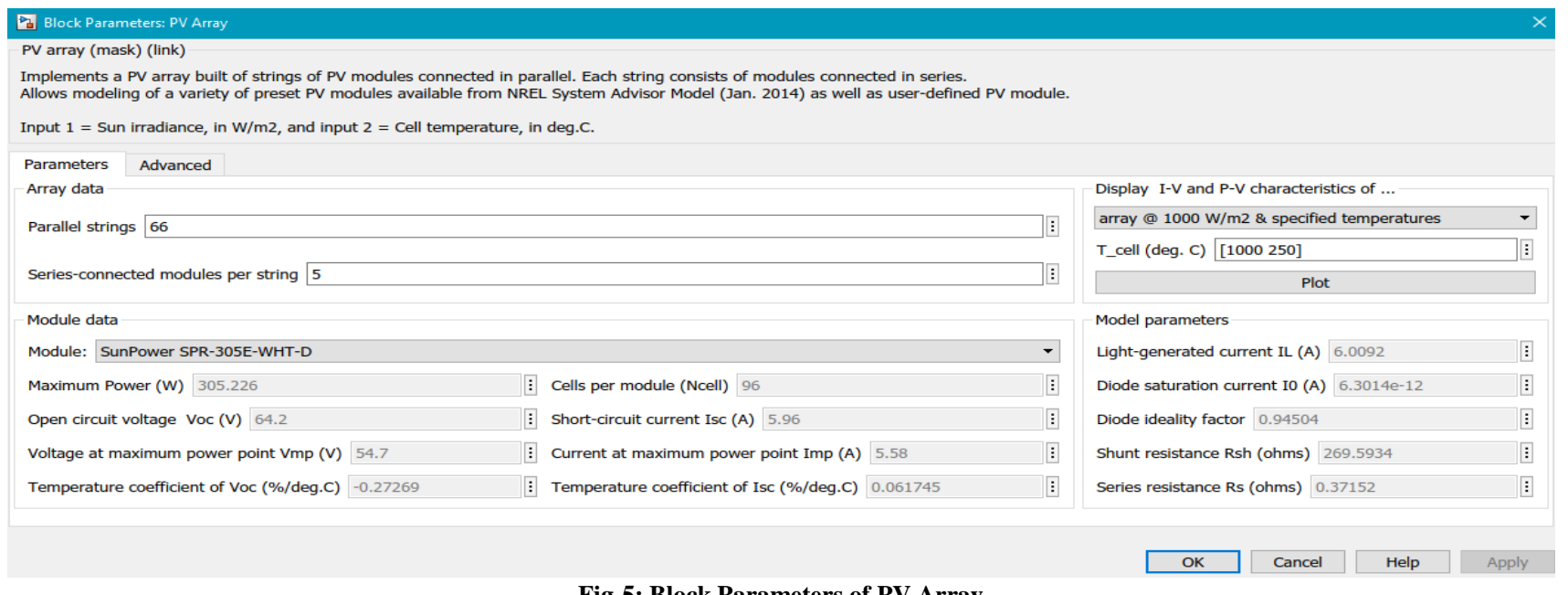

Fig-5: Block Parameters of PV Array

\section{Boost Converter System}

The solar panel voltage is increased by a boost converter. It comprises of an Inductor, Capacitor, IGBT and a diode. DC-DC converters are used to transfer the power of solar panel to load side thus ensuring that maximum power has been transferred which makes use of MPPT. The regulation is achieved by Pulse Width
Modulation (PWM) and the switching device is MOSFET or IGBT. Boost dc-dc converters whose function is to step up DC voltage. Maximum power is reached when MPPT algorithm changes and adjusts the duty cycle of the boost dc-dc converter. The circuit diagram is described in figure- 6 .

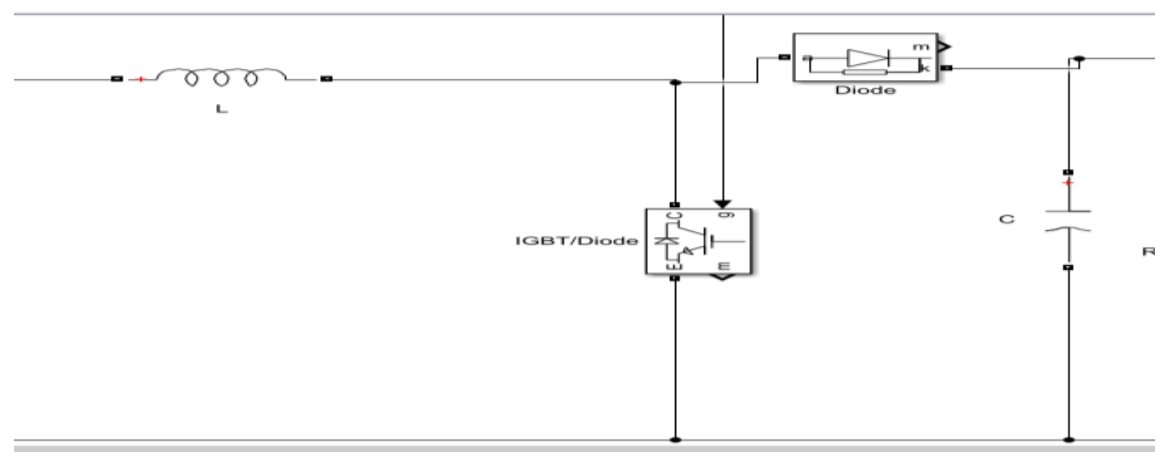

Fig-6: Boost Converter System

The simplified circuit is described in Figure-7. 


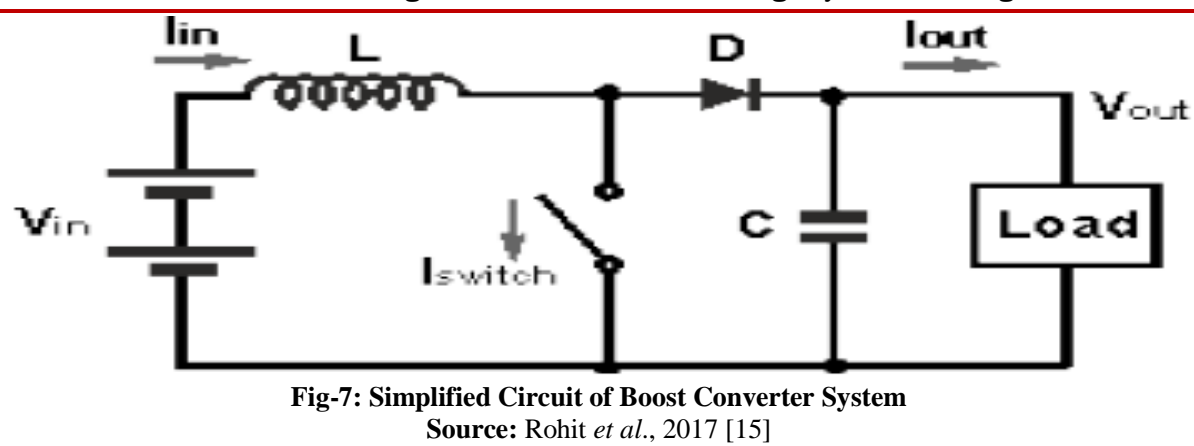

The Boost Converter is used to boost the solar panel output voltage with two modes of operation.

Mode 1: Time cycle switching frequency to determines the mode of operation of the boost converter. With switch closed (ON), power source $\left(\mathrm{V}_{\text {in }}\right)$ makes available the current to charge the inductor and inductor is fully charged. Current through the diode equals zero due to the polarity of capacitor. Therefore capacitor discharges and current through the load is kept constant [16].

Mode 2: With switch opened (OFF), diode is now forward bias. Inductor releases energy that charges and current flowing through the load remains constant. The Simulated System is shown in the block diagram as seen in Figure-8.

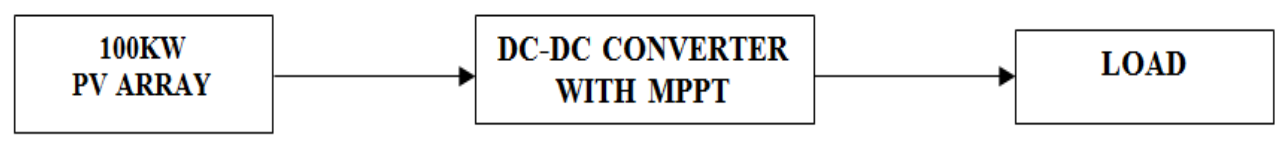

Fig-8: Simulated System

\section{RESULTS AND DISCUSSION}

The SIMULINK model representing $\mathrm{P} \& \mathrm{O}$ and INC MPPT for PV systems is described in Figures 4.1 and 4.2 respectively. The parameter used in the simulation is shown in Table-2 and Simulink (MATLAB GUI). Test is carried out on the models and results compared between $\mathrm{P} \& \mathrm{O}$ and INC MPPT for PV systems. It was found that Photo Current, $\mathrm{I}_{\mathrm{Ph}}$ depends on the temperature and solar insolation which is given in equation 8;

$$
\mathrm{I}_{\mathrm{ph}}=\mathrm{G}\left[\mathrm{I}_{\mathrm{sc}}+\mathrm{K}_{\mathrm{i}}(\mathrm{Tc}-298) \ldots \ldots \ldots \ldots \ldots 8\right.
$$

Where $\mathrm{G}=$ Solar insolation in $\mathrm{KW} / \mathrm{m}^{2}, \mathrm{I}_{\mathrm{sc}}=$ Short circuit current at $25^{\circ} \mathrm{C}$ and $\mathrm{IKW} / \mathrm{m}^{2}(\mathrm{STC}), \mathrm{K}_{\mathrm{i}}=$ Temperature Coefficient, $\mathrm{T}_{\mathrm{c}}=$ Cell Temperature

The Simulink model for computation of $I_{p h}$ is shown in Figure 4.1a

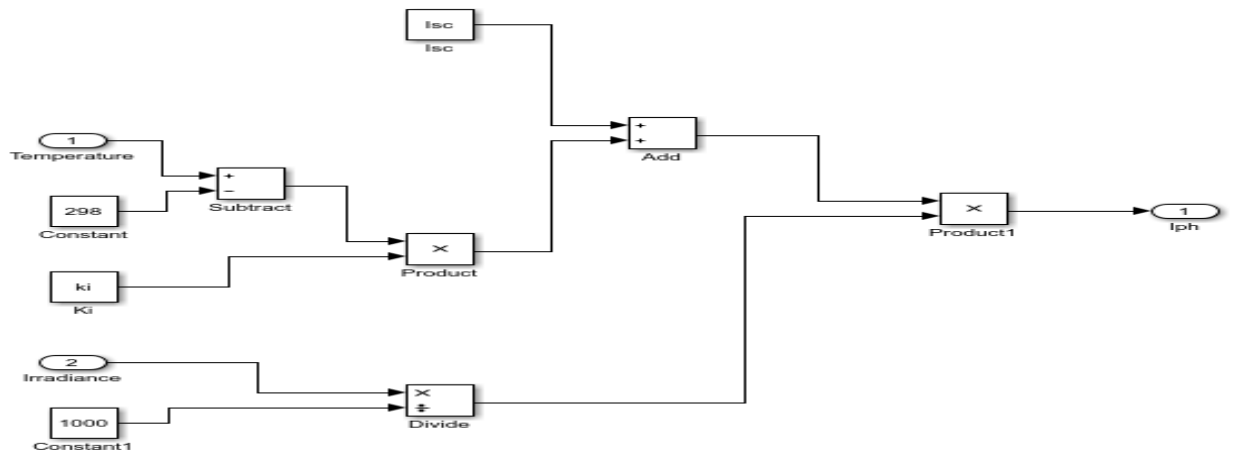

Fig-4.1a: Simulation of module current

For a single diode model of PV cell, the current through the shunt resistor, $\mathrm{I}_{\mathrm{sh}}$ is given as;

$$
\mathrm{I}_{\mathrm{sh}}=\left(\mathrm{V}+\mathrm{I}_{\mathrm{Rs}}\right) / \mathrm{R}_{\mathrm{sh}}
$$

Where $\mathrm{V}=$ output voltage, $\mathrm{I}_{\mathrm{Rs}}=$ series resistance, $\mathrm{R}_{\mathrm{sh}}=$ parallel resistance.
The Simulink model for the calculation of current through the shunt resistance is described in Figure 4.1b 


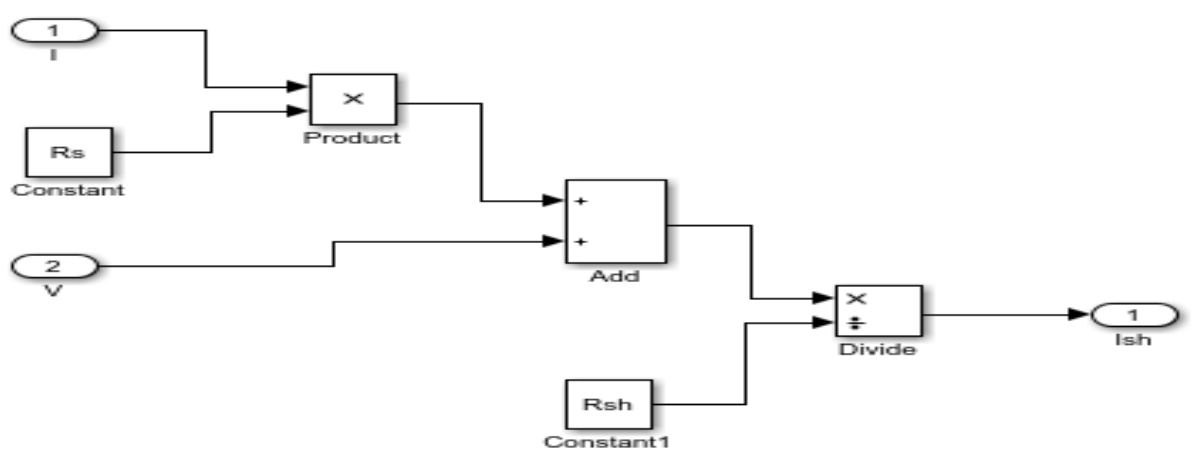

Fig-4.1b: Simulation of Shunt resistance current

The Reverse Saturation current, $\mathrm{I}_{\mathrm{rs}}$ is given as;

$$
\left.\mathrm{I}_{\mathrm{rs}}=\mathrm{I}_{\mathrm{sc}}\left[\exp \left(\mathrm{qV}_{\mathrm{oc}} / \mathrm{N}_{\mathrm{skn}} \mathrm{T}\right)-1\right)\right]
$$

Where; $\mathrm{k}=$ Boltzmann's Constant $(1.3805 \mathrm{x}$ $\left.10^{-23} \mathrm{~J} / \mathrm{K}\right), \mathrm{q}=$ electron charge $\left(1.6 \times 10^{-19} \mathrm{C}\right), \mathrm{V}_{\mathrm{oc}}=$ open circuit voltage, $\mathrm{n}=$ ideality factor of the diode, $\mathrm{N}_{\mathrm{s}}$ $=$ number of cells connected in series, $\mathrm{I}_{\mathrm{sc}}=$ short circuit current. Figure 4.1c shows modeling and simulation of reverse saturation

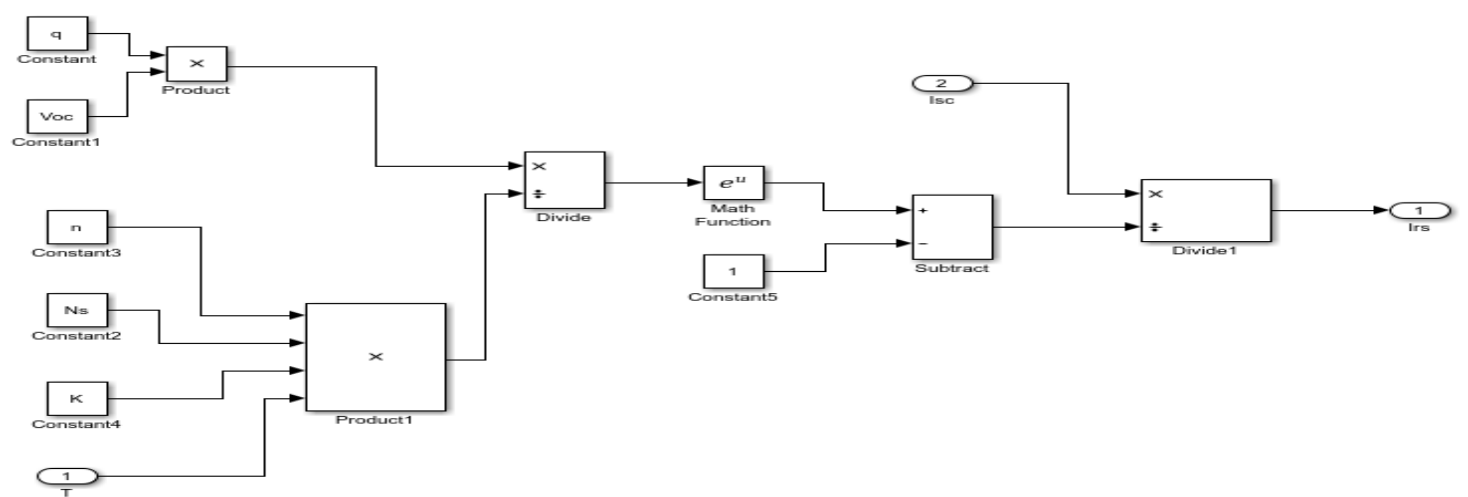

Fig-4.1c: Modeling and Simulation of Reverse saturation current

The Simulink model is described in figure 4.1c

The Saturation current, $\mathrm{I}_{\mathrm{o}}$ is given as;

$$
\mathrm{I}_{\mathrm{o}}=\mathrm{I}_{\mathrm{rs}}\left[\frac{T}{T r}\right]^{3} \exp \left[\frac{q \times E g o}{n k}\left(\frac{1}{T}-\frac{1}{T r}\right)\right] \ldots \ldots .11
$$

Where $\mathrm{E}_{\mathrm{go}}=$ Energy band gap of semiconductors $(1.1 \mathrm{eV}), \mathrm{T}=$ nominal temperature $(298.15 \mathrm{~K})$.

The Simulink model is shown in Figure 4.1d.

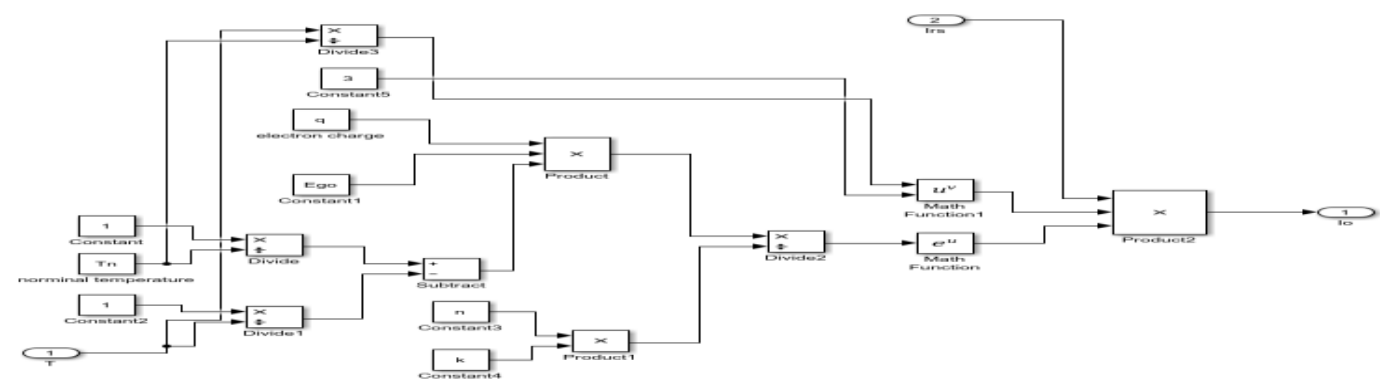

Fig-4.1d: Simulation of Saturation current

\section{Parameters of the Test System}

Simulation model of the test system is shown in Figures 4.2 and 4.3 respectively. The test system parameter is given in Table-2. 


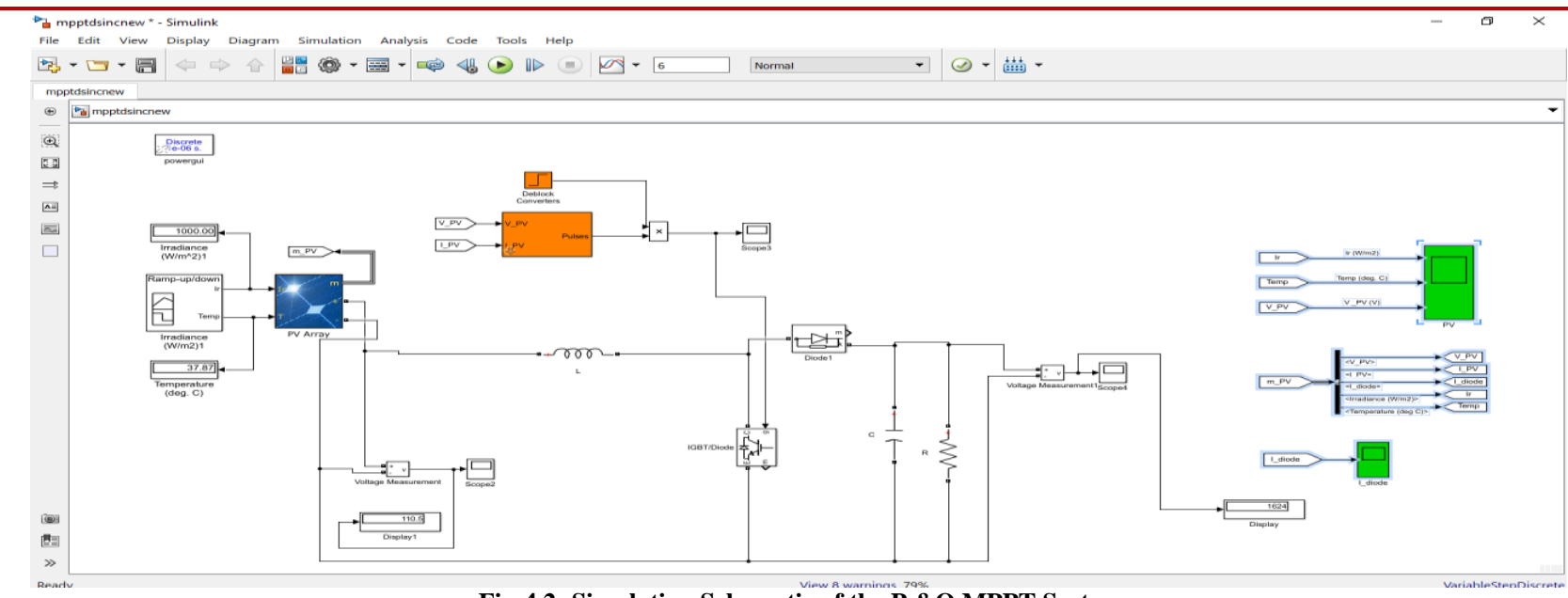

Fig-4.2: Simulation Schematic of the P \&O MPPT System

From figures 4.2 and 4.3 , irradiance and temperatures are the input of the PV array and the output of the array is connected to the boost converter system consisting of an inductor, capacitor, insulatedgate bipolar transistor (IGBT) and diode. MPPT parameters (I_PV and V_PV) are connected to the gate of the IGBT for triggering. When the triggering is done, the signal is sent to a load connected to the output and the voltage is obtained when the irradiance and temperature is varied. This is measured and displayed on the scope.

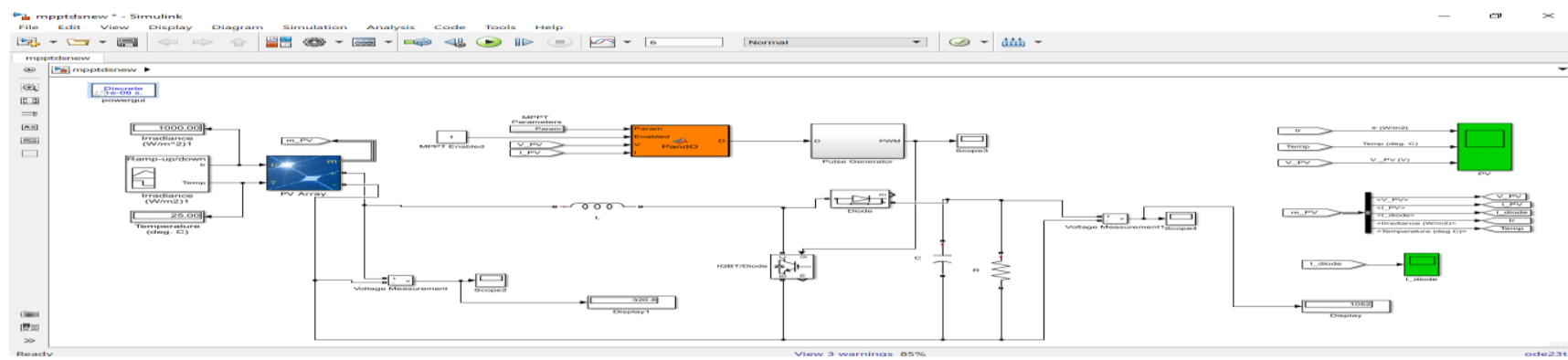

Fig-4.3: Simulation Schematic of P\&O MPPT System

The temperature and irradiance is inputted into the system using a signal builder. The simulation time of INC and P\&O is $2.5 \mathrm{~s}$ and $6.0 \mathrm{~s}$ respectively. The test carried out is to check the response of MPPT system to the change in irradiance and temperature and the simulation was run on P\&O and INC MPP.

\section{Perturb and Observe MPPT}

The temperature and irradiance parameters are used in running the test and values obtained from MPPT system is shown in Table-2.

Table-2: Parameter for Perturb and Observe MPPT

\begin{tabular}{|l|l|l|l|}
\hline $\mathbf{S} / \mathbf{N}$ & Irradiance $\left(\mathbf{W} / \mathbf{m}^{\mathbf{2}}\right)$ & Temperature $\left({ }^{\circ} \mathbf{C}\right)$ & Voltage (kilo-volt) \\
\hline 1 & 1000 & 25 & 1.040 \\
\hline 2 & $1000-250$ & 25 & $0.996-0.689$ \\
\hline 3 & 250 & 25 & 0.690 \\
\hline 4 & $250-1000$ & 25 & $0.690-1.003$ \\
\hline 5 & 1000 & $25-40$ & $1.003-0.968$ \\
\hline 6 & 1000 & 40 & 0.967 \\
\hline 7 & 1000 & $40-20$ & $0.967-1.017$ \\
\hline 8 & 1000 & 20 & 1.021 \\
\hline
\end{tabular}

Table-2 shows the parameter that was used to test the model and the output voltage value obtained from MPPT. The test carried out is done by varying both the irradiance and temperature entering the solar panel .This will affect the voltage and power produced by the solar panel as shown in Tables $2 \& 3$ and Figures $4.4,4.5,4.6$ and 4.7 respectively. 
Omorogiuwa Eseosa \& Itelema Kingsley., Saudi J Eng Technol, Feb. 2020; 5(2): 38-48

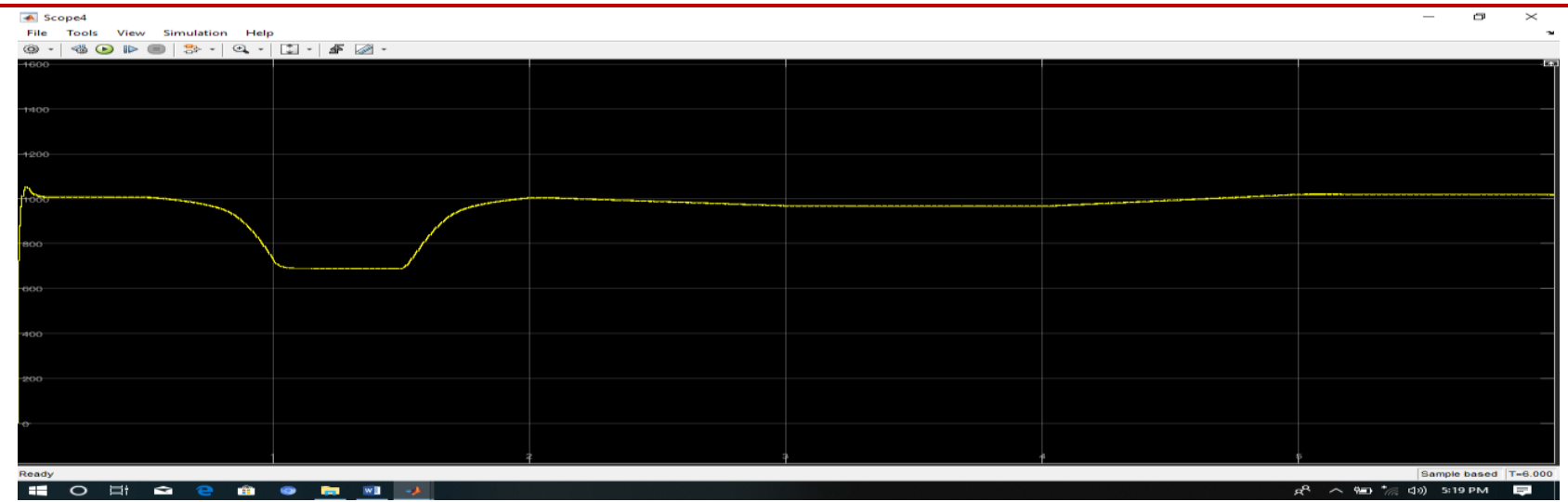

Figure 4.4: Voltage Graph of Perturb and Observe MPPT

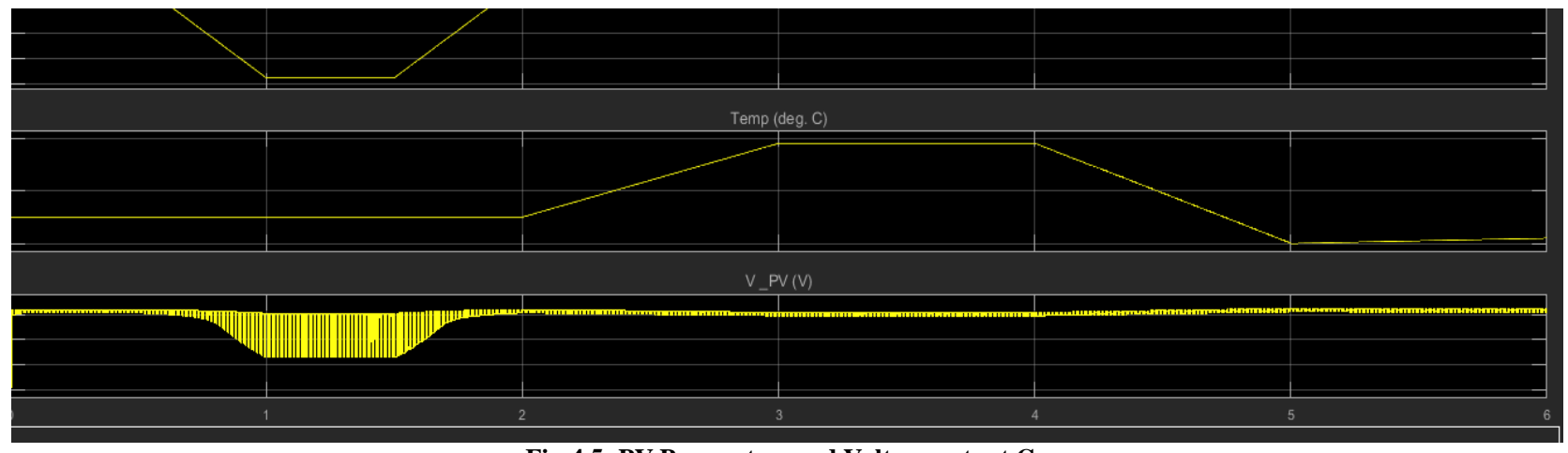

Fig-4.5: PV Parameters and Voltage output Curve

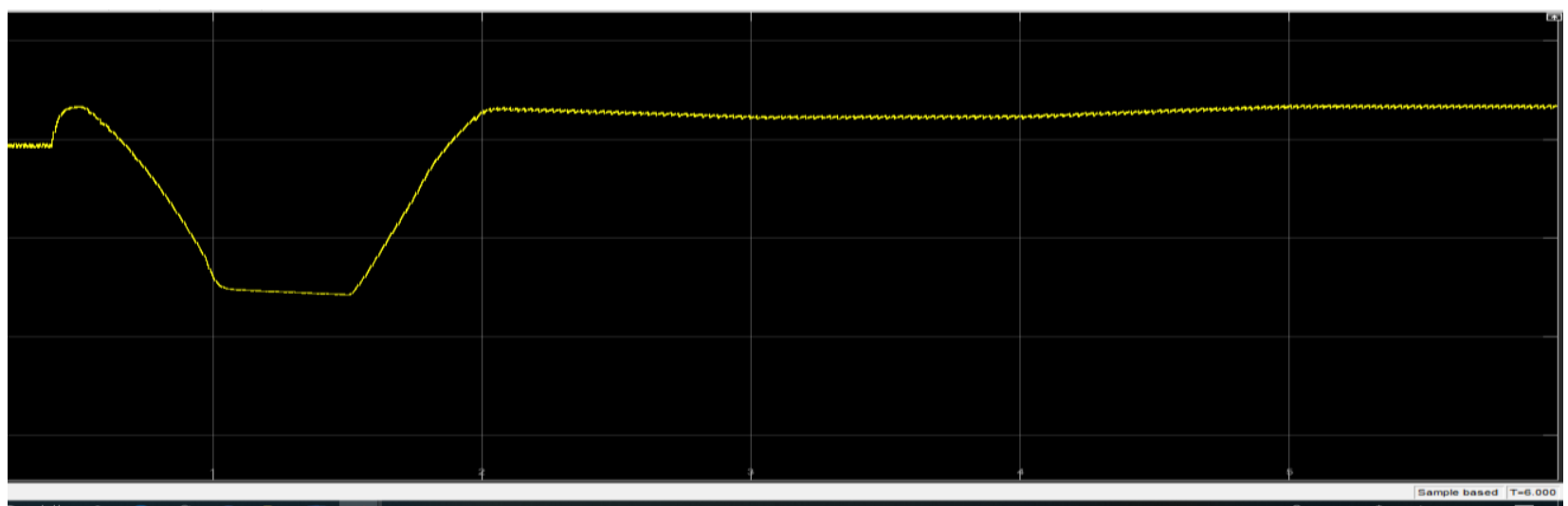

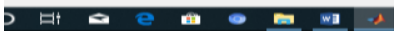

Fig-4.6: Voltage Graph of Incremental Conductance MPPT

A PV

File Tools View Simulation Help

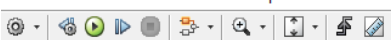

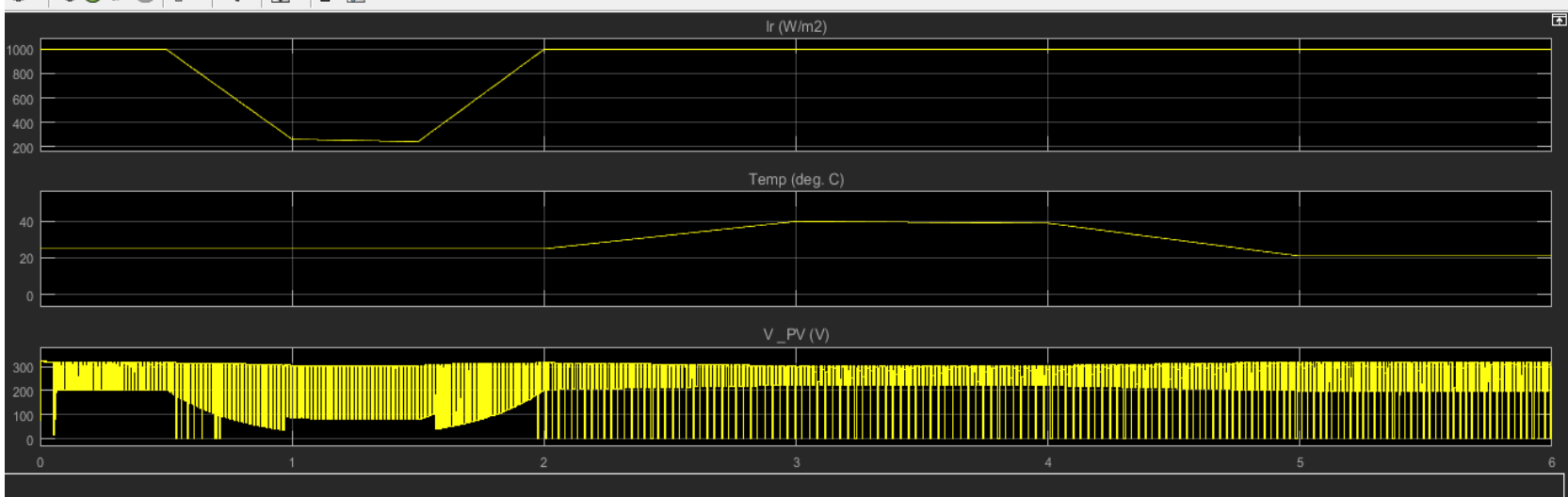

Fig-4.7: PV Parameters and Voltage output Curve 
From Table-2, figure 4.4 and 4.5 , it was observed that, when irradiance equals to $1000 \mathrm{w} / \mathrm{m}^{2}$, the temperature $=25^{\circ} \mathrm{C}$; From time $0.0 \mathrm{~s}$ to $0.5 \mathrm{~s}$, the voltage was $1.040 \mathrm{kV}$ and power produced by the solar panel was constant. From time $0.5 \mathrm{~s}$ to $1.0 \mathrm{~s}$, when irradiance was reduced from $1000 \mathrm{w} / \mathrm{m}^{2}$ to $250 \mathrm{w} / \mathrm{m}^{2}$ and temperature was still kept at $25^{\circ} \mathrm{C}$, there was a decrease in power as the voltage was reduced from $0.966 \mathrm{kV}$ to $0.690 \mathrm{kV}$. From time $1.0 \mathrm{~s}$ to $1.5 \mathrm{~s}$, when irradiance and temperature was kept at $250 \mathrm{w} / \mathrm{m}^{2}$ and $25^{\circ} \mathrm{C}$, the voltage was constant at $0.690 \mathrm{kV}$. From time $1.5 \mathrm{~s}$ to $2.0 \mathrm{~s}$, the irradiance was increased from $250 \mathrm{w} / \mathrm{m}^{2}$ to $1000 \mathrm{w} / \mathrm{m}^{2}$ and temperature at $25^{\circ} \mathrm{C}$, the voltage increased slightly from $0.690 \mathrm{kV}$ to $1.003 \mathrm{kV}$. From time $2.0 \mathrm{~s}$ to $3.0 \mathrm{~s}$, with irradiance at $1000 \mathrm{w} / \mathrm{m}^{2}$ and temperature raised from $25^{\circ} \mathrm{C}$ to $40^{\circ} \mathrm{C}$, the voltage reduced slightly from
$1.003 \mathrm{kV}$ to $0.968 \mathrm{kV}$. From time $3.0 \mathrm{~s}$ to $4.0 \mathrm{~s}$, with irradiance and temperature kept at $1000 \mathrm{w} / \mathrm{m}^{2}$ and $40^{\circ} \mathrm{C}$, the voltage was kept constant at $0.968 \mathrm{kV}$. From time $4.0 \mathrm{~s}$ to $5.0 \mathrm{~s}$, with irradiance still kept at $1000 \mathrm{w} / \mathrm{m}^{2}$ and temperature reduced from $40^{\circ} \mathrm{C}$ to $20^{\circ} \mathrm{C}$, the voltage slightly increased from $0.968 \mathrm{kV}$ to $1.017 \mathrm{kV}$. From time $5.0 \mathrm{~s}$ to $6.0 \mathrm{~s}$, with irradiance and temperature at $1000 \mathrm{w} / \mathrm{m}^{2}$ and $20^{\circ} \mathrm{C}$, the voltage obtained was $1.021 \mathrm{kV}$. This is the maximum voltage and it is obtained when temperature is minimum.

\section{Incremental Conductance MPPT}

The temperature and irradiance parameters used in performing the test and the values obtained as the power from MPPT system is shown in Table-3.

Table-3: Parameter for Incremental Conductance MPPT

\begin{tabular}{|l|l|l|l|}
\hline $\mathbf{S} / \mathbf{N}$ & Irradiance $\mathbf{( W / \mathbf { m } ^ { 2 } )}$ & Temperature (Degrees) & Voltage (kilo-volt) \\
\hline 1 & 1000 & 25 & 1.447 \\
\hline 2 & $1000-250$ & 25 & $1.082-0.8276$ \\
\hline 3 & 250 & 25 & 0.727 \\
\hline 4 & $250-1000$ & 25 & $0.727-1.619$ \\
\hline 5 & 1000 & $25-40$ & $1.619-1.614$ \\
\hline 6 & 1000 & 40 & 1.500 \\
\hline 7 & 1000 & $40-20$ & $1.500-1.668$ \\
\hline 8 & 1000 & 20 & 1.673 \\
\hline
\end{tabular}

Table- 3 shows the parameter used to test the model and the output voltage value obtained from the MPPT.

From Table-3, Figures 4.6 and 4.7 , it was observed that, when irradiance $=1000 \mathrm{w} / \mathrm{m}^{2}$ the temperature $=25^{\circ} \mathrm{C}$; From time $0.0 \mathrm{~s}$ to $0.5 \mathrm{~s}$, the voltage was $1.447 \mathrm{kV}$. From time $0.5 \mathrm{~s}$ to $1.0 \mathrm{~s}$, when irradiance was reduced from $1000 \mathrm{w} / \mathrm{m}^{2}$ to $250 \mathrm{w} / \mathrm{m}^{2}$ and temperature was still kept at $25^{\circ} \mathrm{C}$, there was a decrease in power as the voltage was reduced from $1.082 \mathrm{kV}$ to $0.827 \mathrm{kV}$. From time $1.0 \mathrm{~s}$ to $1.5 \mathrm{~s}$, when irradiance and temperature was kept at $250 \mathrm{w} / \mathrm{m}^{2}$ and $25^{\circ} \mathrm{C}$, the voltage further reduced to $0.745 \mathrm{kV}$. From time $1.5 \mathrm{~s}$ to $2.0 \mathrm{~s}$, the irradiance was increased from $250 \mathrm{w} / \mathrm{m}^{2}$ to $1000 \mathrm{w} / \mathrm{m}^{2}$ and temperature at $25^{\circ} \mathrm{C}$, the voltage increased rapidly from $0.727 \mathrm{kV}$ to $1.619 \mathrm{kV}$. From time $2.0 \mathrm{~s}$ to $3.0 \mathrm{~s}$, with irradiance at $1000 \mathrm{w} / \mathrm{m}^{2}$ and temperature raised from $25^{\circ} \mathrm{C}$ to $40^{\circ} \mathrm{C}$, the voltage reduced slightly from $1.619 \mathrm{kV}$ to $1.614 \mathrm{kV}$. From time $3.0 \mathrm{~s}$ to $4.0 \mathrm{~s}$, with irradiance and temperature kept at $1000 \mathrm{w} / \mathrm{m}^{2}$ and $40^{\circ} \mathrm{C}$, the voltage further reduced to $1.500 \mathrm{kV}$. From time $4.0 \mathrm{~s}$ to $5.0 \mathrm{~s}$, with irradiance still kept at $1000 \mathrm{w} / \mathrm{m}^{2}$ and temperature reduced from $40^{\circ} \mathrm{C}$ to $20^{\circ} \mathrm{C}$, the voltage slightly increased from $1.500 \mathrm{kV}$ to $1.668 \mathrm{kV}$. From time $5.0 \mathrm{~s}$ to $6.0 \mathrm{~s}$, with irradiance and temperature at $1000 \mathrm{w} / \mathrm{m}^{2}$ and $20^{\circ} \mathrm{C}$, the voltage obtained was $1.673 \mathrm{kV}$. This is the maximum voltage and it is obtained when temperature is minimum, hence for the INC MPPT, voltage increases and reduces rapidly irrespective of the change in irradiance and temperature.

\section{CONCLUSION}

The graph shown in Figures 4.3 and 4.5 is derived from the scope used in showing the effect of MPPT system of both methods. The graph shows that when the irradiance and temperature is constant, both MPPT systems worked efficiently by raising solar panel power, hence increasing the output voltage. The voltage derived from the output in incremental conductance MPPT system is higher than perturb and observe. From time 0.5 to $1.0 \mathrm{~s}$, the temperature was constant but the irradiance of the system is ramped down from 1000 $\mathrm{W} / \mathrm{m}^{-2}$ to $250 \mathrm{~W} / \mathrm{m}^{-2}$. With decrease in irradiance, both perturb \& observe and the incremental conductance ramp down. Perturb and observe voltage reduces steadily than the incremental and conductance method that reduces rapidly. From time $1.0 \mathrm{~s}$ to $1.5 \mathrm{~s}$ when the temperature and irradiance was constant, both methods were stable and maintained a steady voltage and power. From time $1.5 \mathrm{~s}$ to $2.0 \mathrm{~s}$ when the temperature was constant but the irradiance of the system is ramped up from $250 \mathrm{~W} / \mathrm{m}^{-2}$ to $1000 \mathrm{~W} / \mathrm{m}^{2}$, the MPPT of both methods ramped up with respect to the increase in irradiance. The voltage of perturb and observe method increases steadily than the incremental and conductance method that reduces rapidly. From time $1.5 \mathrm{~s}$ to $6 \mathrm{~s}$ when the sun irradiance is restored to $1000 \mathrm{~W} / \mathrm{m}^{2}$ and temperature is varied between $40^{\circ} \mathrm{C}$ and $20^{\circ} \mathrm{C}$, the maximum voltage was obtained at minimum temperature of $20^{\circ} \mathrm{C}$. In other words, the MPPT controller of both methods efficiently tracks maximum power only when irradiance stays constant. 


\section{ACKNOWLEDGEMENT}

The authors would like to acknowledge the management and staff of eseogietec engineering company limited (www.eseogietec.com) for all their support academically, materially and financially towards the completion of this task. Their facilities were indeed very useful for this task and the researchers would like to recommend them to other fellow researchers.

\section{APPENDIX A}

function D $=$ PandO $($ Param, Enabled, V, I $)$

\% MPPT controller based on the Perturb \& Observe algorithm.

$\% \mathrm{D}$ output $=$ Duty cycle of the boost converter (value between 0 and 1 )

$\%$

$\%$ Enabled input $=1$ to enable the MPPT controller

$\% \mathrm{~V}$ input $=\mathrm{PV}$ array terminal voltage $(\mathrm{V})$

$\%$ I input $=\mathrm{PV}$ array current $(\mathrm{A})$

$\%$

$\%$ Param input:

Dinit $=$ Param(1); \% Initial value for D output

Dmax $=$ Param(2); \%Maximum value for D

Dmin $=$ Param $(3) ; \%$ Minimum value for $\mathrm{D}$

deltaD $=$ Param(4); \% Increment value used to increase/decrease the duty cycle D

$\%$ (increasing $\mathrm{D}=$ decreasing Vref)

$\%$ persistent Vold Pold Dold;

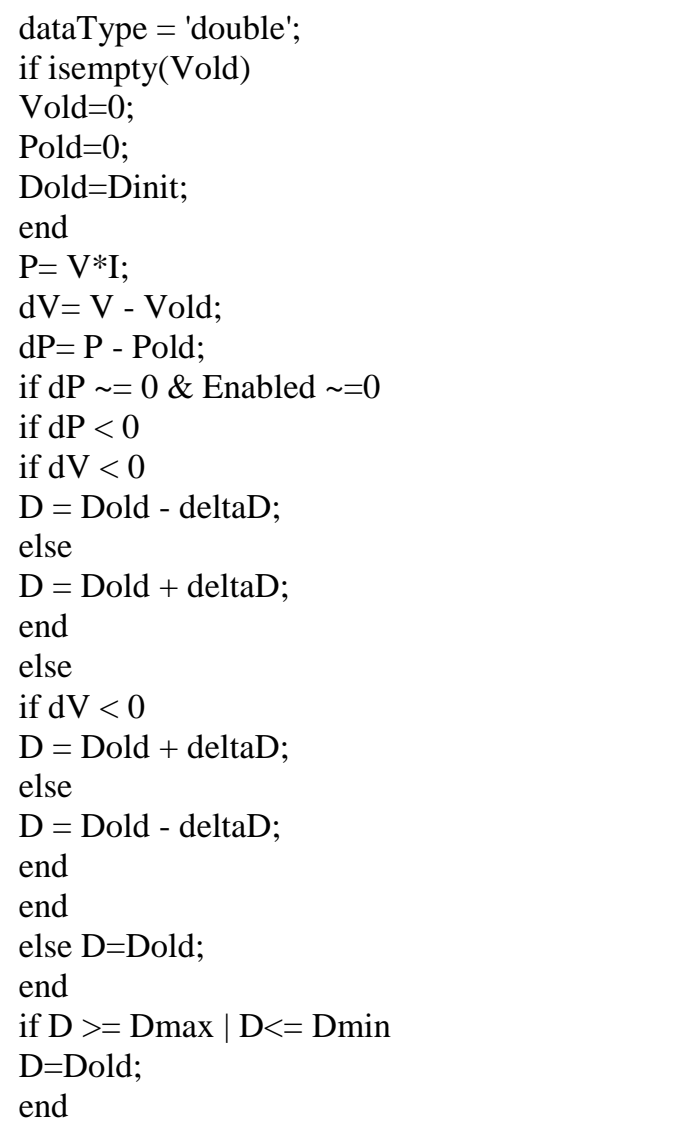

Dold=D;

Vold $=$ V;

Pold=P;

\section{REFERENCES}

1. Khatib, T., \& Sopian, K. (2012). A review of solar energy modeling methods Renew. Sustain. Energy Rev. 16, 2864-2869.

2. Kumar, M. Kapoor, S. R. Nagar, R., \& Verma, A. (2015). Comparison between IC and Fuzzy Logic MPPT Algorithm Based Solar PV System using Boost Converter. International Journal of Advanced Research in Electrical, Electronics and Instrumentation Engineering, 4(6), 4927-4939.

3. Liu, L., Oza, S., Hogan, D., Perin, J., Rudan, I., Lawn, J. E., ... \& Black, R. E. (2015). Global, regional, and national causes of child mortality in 2000-13, with projections to inform post-2015 priorities: an updated systematic analysis. The Lancet, 385(9966), 430-440.

4. Revankar, P. S., Gandhare, W. Z., \& Thosar, A. G. (2010). Maximum power point tracking and efficiency enhancements for PV systems. International Journal of Computer Applications, 1(27).

5. Zainudin, H. N., \& Saad, M. (2010). Comparison Study of Maximum Power Point Tracker Techniques for PV Systems", Proc. 14th International Middle East Power Systems Conference (MEPCON $\left.{ }^{e c} 10\right)$, Cairo University, Egypt, 750-755.

6. Christopher, I. W., \& Ramesh, R. (2013). Comparative study of $\mathrm{P} \& \mathrm{O}$ and InC MPPT algorithms. American Journal of Engineering Research (AJER), 2(12), 402-408.

7. Libo, W., Zhengming, Z., \& Jianzheng, L. (2007). A single-stage three-phase grid-connected photovoltaic system with modified MPPT method and reactive power compensation. IEEE Transactions on Energy Conversion, 22(4), 881886.

8. Ali A., Saied, M., Mostafa, M., \& Moneim, T. (2012). A survey of maximum PPT techniques of PV Systems. Energytech, 2012 IEEE.

9. Jusoh, A., Sutikno T., Guan, T. K., \& Mekhilef, S. (2014). A Review on favourable maximum power point tracking systems in solar energy application. Telkomnika, 12(1):6-22.

10. Lyden, S., \& Haque, M. E. (2015). " Maximum Power Point Tracking techniques for photovoltaic systems: A comprehensive review and comparative analysis, 52, 1504-1518.

11. Kinjal, P., Shah, K. B., \& Patel, G. R. (2015). Comparative Analysis of $\mathrm{P} \& \mathrm{O}$ and INC MPPT Algorithm for PV System 2015 (ICEESCO).

12. Desai-Hardik P., \& Patel, H. K. (2013). Maximum Power Point Algorithm in PV 
Generation: An Overview; IEEE Research, 2009, 624-629.

13. Logeswaran, T., \& Senthil-Kumar, A. (2014). A Review of maximum power point tracking algorithms for photovoltaic systems under uniform and non-uniform irradiances, 4th International Conference on Advances in Energy Research 2013, ICAER 2013. Energy Procedia, 54, 228235.

14. MacIsaac, L., \& Knox, A. (2010). Improved Maximum Power Point Tracking Algorithm for
Photovoltaic Systems International Conference on Renewable Energies and Power Quality (ICREPQ'10) Granada (Spain), 239-244

15. Rohit, K. (2017). International Journal of Advanced Research in Computer Science and Software Engineering. 7(4).

16. Marcelo, G., Gazoli, J., \& Filho, E. (2010). Comprehensive Approach to Modeling and Simulation of Photovoltaic Arrays. IEEE Transactions on Power Electronics, 24(5), 11981208. 